\title{
Peran Organisasi Desa dalam Pembangunan di Taiwan, Thailand, dan Philipina: Suatu Studi Komparasi
}

\author{
Budi Winarno
}

\section{Permasalahan:}

ebagaimana halnya di banyak negara berkembang, pemerintah-pemerintah Taiwan, Thailand dan Philipina mempunyai komitmen yang semakin meningkat untuk menyelenggarakan pembangunan desa. Pemerintah memandang pembangunan desa memainkan peran yang sangat krusial dalam konteks pembangunan nasional dan sekaligus merupakan upaya untuk menanggulangi masalah-masalah pedesaan, misalnya produktivitas pertanian, pengangguran dan kemiskinan. Penanggulangan masalah-masalah ini akan mempunyai makna tidak saja memperbaiki atau meningkatkan harkat dan martabat kehidupan rakyat di daerah-daerah perdesaan, tetapi juga dapat meningkatkan legitimasi pemerintah.

Untuk menunjang pelaksanaan pembangunan desa, pemerintah-pemerintah Taiwan, Thailand, Philipina telah membentuk organisasi desa. Peran lembaga-lembaga petani dapat digolongkan dalam tiga kegiatan utama. Pertama, organisasi-organisasi petani membagi-bagikan input-in- put produksi pertanian kepada para petani. Kedua, organisasi petani memberikan pelayanan sosial dan infrastruktur ke daerahdaerah pedesaan. Ketiga, organisasi petani juga mempunyai peran dalam mendorong penduduk desa untuk berpartisipasi dalam pembuatan keputusan desa maupun melindungi kepentingan-kepentingan petani yang lemah ekonominya.

Dibandingkan peran organisasi desa di Thailand dan Philipina, organisasi-organisasi petani di Taiwan memainkan peran sangat efektif dalam mendukung program pembangunan desa. Tulisan ini akan menjelaskan mengapa organisasi-organisasi petani di Taiwan dipandang efektif dalam melakukan kegiatan seperti yang telah disebutkan dalam menunjang pembangunan desa. Sementara di Thailand dan Philipina terjadi hal yang sebaliknya, yaitu organisasi-organisasi desa memberikan sumbangan yang kecil dalam proses pembangunan desa. Kelemahan-kelemahan apá yang ada dalam organisasi-organisasi petani di dua negara ini, sehingga peran mereka tidak bermakna dalam pembangunan? 


\section{Kerangka Teoritik}

Untuk menjawab masalah seperti yang diuraikan sebelumnya, perlu dibahas terlebih dulu kerangka konseptual yang dipakai sebagai landasan pijakan menjawab masalah itu: Dalam kerangka teoritik ini, penulis mencoba membahas model-model dan pendekatan-pendekatan pembangunan desa yang menurut pengalaman penulis sangat mempengaruhi peran organisasiorganisasi desa.

\section{Model-model Pembangunan Desa}

Strategi-strategi pembangunan desa di negara-negara Dunia Ketiga menganut tiga model pembangunan. Pertama adalah model intervensi rendah atau disebut pula model produktivitas. Kedua adalah model intervensi menengah atau dinamakan pula model solidaritas. Ketiga adalah model intervensi tinggi atau disebut pula model equality atau pemerataan (Inayatullah, 1979).

Model Intervensi Rendah. Dalam mengimplementasikan kebijaksanaan pembangunan desa, pemerintah mungkin menggunakan model intervensi rendah atau model produktivitas. Menurut model ini upaya pemerintah ditujukan untuk meningkatkan produktivitas pertanian tanpa memandang pertu melakukan perubahan-perubahan penting dan substansial struktur sosial dan sistem pemilikan tanah. Diagnosa utama dari keterbelakangan pedesaan (rural underdevelopment) adalah langkanya teknologi yang dapat meningkatkan produktivitas, ketidaktahuan atau kebodohan, ketahayulan, buta aksara dan angka, merupakan fenomena umum di kalangan penduduk desa.

Strategi pembangunan yang dituntut oleh model intervensi rendah adalah membantu penduduk desa yang mempunyai modal, sumber-sumber, ketrampilan dan moti- vasi yang besar untuk meningkatkan produktivitas pertanian mereka. Oleh karena itu, pemerintah harus memberikan banyak perhatian kepada penduduk desa yang masuk dalam kategori ini dengan memberikan kemudahan-kemudahan kepada mereka untuk memperoleh input-input bagi produktivitas yang tinggi dan pembaharuan-pembaharuan teknis. Pemerintah juga perlu memberikan insentif yang lebih besar kepada penduduk desa yang mengorganisi produksi bagi pertukaran dan keuntungan dan bukan untuk konsumsi sendiri. Dalam model ini prioritas-prioritas ditentukan oleh kekuatankekuatan pasar dan tidak ada perubahanperubahan struktural, seperti landreform. Penerima keuntungan yang paling besar dari pembangunan desa, yang mendasarkan pada penggunaan model intervensi rendah atau model produktivitas ini adalah lapisan penduduk desa yang memiliki tanah atau sawah yang luas, karena mereka dapat memperoleh input-input yang sangat diperlukan untuk menghasilkan produktivitas pertanian yang tinggi.

Dorongan untuk memperoleh produktivitas pertanian yang tinggi dengan memberikan perhatian yang besar kepada lapisan penduduk desa yang memiliki tanah luas dan di samping pemerintah, menempuh cara mekanisasi maupun komersialisasi pertanian, secara perlahan-lahan dampak pembangunan desa akan menimbulkan kemerosotan sosial dan ekonomi dalam masyarakat. Hubungan-hubungan tradisional antara beberapa kelompok sosial di pedesaan secara meningkat akan bersifat ekonomis, dan banyak penyewa, petani bagi hasil dan petani kecil/gurem menjadi buruh tani yang diupah. Di samping model intervensi rendah mempunyai ciri produksi ditentukan oleh kekuatan-kekuatan pasar, model ini diimplementasikan oleh field agents dari birokrasi tingkat nasional yang mempunyai hubungan-hubungan dengan 
lapisan penduduk menengah dan atas di daerah-daerah pedesaan yang pada umumnya melayani dan membantu kepentingan mereka.

Model Intervensi Menengah atau Solidaritas. Dalam model ini diagnosa utama penyebab pokok keterbelakangan pedesaan (rural underdevelopment) adalah kemerosotan dan degenerasi masyarakat desa dan langkanya lembaga-lembaga desa yang dapat meningkatkan peran serta aktif penduduk desa. Oleh karena itu, masalahmasalah tersebut dapat dipecahkan dengan membentuk lembaga-lembaga pedesaan baru, memodernisasikan elit desa, dan mendefusikan ketrampilan-ketrampilan organisasi dan hubungan manusia.

Model intervensi menengah ini memperkenalkan intervensi yang terbatas dalam lembaga-lembaga desa dengan melakukan perubahan-perubahan yang bersifat moderat dalam sistem pemilikan tanah dan dalam struktur kekuasaan desa. Dengan demikiàn, dapat dikatakan bahwa model pembangunan desa ini bersifat toleran terhadap tingkat ketidakmerataan (inequality) yang cukupan, dan bersifat ambivalen mengenai tingkat di mana sistem sosial pedesaan tradisional perlu dimodernisir dan struktur kekuasaan tradisional yang perlu diperlemah untuk melembagakan strukturstruktur kekuasaan baru yang mampu meningkatkan peran serta aktif penduduk desa.

Model ini dimaksudkan untuk memperoleh tingkat integrasi perencanaan dan pembangunan pada tingkat nasional dan tingkat lokal. Di samping itu, pemerintah yang menganut model ini tidak perlu melakukan program-program industrialisasi yang penting di daerah-daerah pedesaan. tetapi pemerintah lebih mengutamakan pengembangan kerajinan tangan pedesaan. Model intervensi menengah juga mendorong kegiatan-kegiatan koperasi dengan membentuk dan memberikan kredit yang berasal dari masyarakat desa, membentuk koperasi-koperasi konsumen dan pemasaran, yang bertujuan mengurangi kegiatan-kegiatan ekonomi yang eksploitatif di daerah-daerah pedesaan dan untuk memperkuat kedudukan ekonomi produsen dan konsumen di desa.

Lapisan masyarakat desa yang menerima keuntungan dari pembangunan desa yang mendasarkan pada model intervensi menengah atau model solidaritas adalah kelas menengah pedesaan, yang pada umumnya memperoleh bagian terbesar dari bantuan atau sumber-sumber yang diberikan oleh pemerintah dalam program-program pembangunan desa. Organisasi-organisasi lapangan yang membantu birokrasi pemerintah diorganisir dalam bentuk kelompok-kelompok sukarela yang kecil, seperti koperasi-koperasi yang mempunyai tujuan memperkuat kedudukan ekonomi dan politik organisasi-organisasi itu. Namun demikian, dalam perkembangannya kelompokkelompok sukarela itu dapat menimbulkan konflik dengan birokrasi lokal. Karena model ini tidak mengikutsertakan para pemilik tanah sempit, penyewa dan buruh tani yang tidak mempunyai lahan pertanian, maka para petani yang berpenghasilan rendah ini menjauhkan diri dari program-program pertanian. Sebagai suatu strategi pembangunan desa, model intervensi menengah dianggap kurang efektif dalam mencapai tujuan-tujuan pembangunan desa, karena tidak berhasil dalam memberikan pelayanan-pelayanan secara sukarela dan mendorong semangat komunitas di antara para pemilik tanah sempit, penyewa dan buruh tani.

Model Intervensi Tinggi atau Model Pemerataan (Equality). Model ini mengatakan bahwa tidak meratanya pendapatan, kekayaan dan kekuasaan di kalangan penduduk desa merupakan penyebab utama 
keterbelakangan desa (rural underdevelopment). Nilai-nilai, tingkah laku, lembagalembaga desa yang lemah dan tidak adanya teknologi yang mampu meningkatkan dan memperbaiki produktivitas pertanian, yang dua model sebelumnya menganggap penyebab rural underdevelopment, dipandang oleh model ini hanya sebagai suatu gejala adanya kemiskinan penduduk desa karena kurang tersedianya kesempatankesempatan dan sumber-sumber yang dimiliki oleh lapisan penduduk desa yang miskin.

Menurut model ini, pembangunan desa memerlukan perjuangan dua arah. Perta$m a$, penguasaan aparat-aparat pemerintah pada tingkat nasional melalui organisasiorganisasi politik yang relevan oleh lapisan masyarakat bawah untuk memudahkan transformasi masyarakat secara radikal. Kedua, perjuangan yang diorganisir menentang kelompok petani kaya pada tingkat lokal dengan jalan petani yang berpenghasilan rendah mengambil alih struktur kekuasaan lokal dan mendistribusikan tanah dan sarana-sarana produksi lain. Menurut model ini, munculnya struktur hubungan sosial baru menghendaki alokasi sumbersumber yang bersifat rasional, pengembangan teknologi yang tepat guna dan penanggulangan rural underdevelopment dapat dilaksanakan.

Model ini mula-mula menyarankan intervensi secara besar-besaran yang dilakukan oleh aparat-aparat negara yang muncul dalam semua aspek kehidupan sosial yang dikuasai oleh organisasi-organisasi yang berorientasi kepada kepentingan lapisan masyarakat bawah di daerah-daerah pedesaan. Tingkat intervensi ini mungkin dikurangi, apabila hubungan-hubungan sosial yang mendasar telah berubah, yaitu setelah masyarakat dapat berfungsi dalam suatu cara yang lebih didesentralisasikan.
Tujuan utama dari model intervensi tinggi adalah mempersempit atau kalau mungkin menghapuskan ketidakmerataan sosial, ekonomi dan kebudayaan serta kegiatan-kegiatan ekonomi kelompok penduduk desa yang kaya akan dapat merugikan kepentingan lapisan penduduk yang berpenghasilan rendah. Dengan jalan melakukan perubahan-perubahan dalam pola-pola pemilikan tanah, yang biasanya dimulai dengan program-program pembagian tanah kpada kelompok petani penanam dan buruh yang tidak mempunyai lahan pertanian, model intervensi tinggi pada akhirnya ingin menciptakan perusahaan-perusahaan pertanian kolektif. Ini menjadi sumber masalah besar dalam model ini. Para penerima tanah merasa enggan melepaskan tanah kembali untuk tujuan-tujuan kolektif, kecuali jika kepada para petani itu diperkenalkan indoktrinasi ideologi dan mendapat tekanan sosial dan kekerasan fisik dari pemerintah.

\section{Organisasi Desa}

Organisasi-organisasi desa, seperti koperasi-koperasi desa yang disponsori oleh pemerintah, organisasi-organisasi pemerintah daerah desa, perhimpunan-perhimpunan petani yang disponsori oleh pemerintah, organisasi-organisasi pemuda dan wanita (Inayatullah, 1978) dinilai mempunyai peran yang sangat krusial dalam pembangunan di banyak negara berkembang. Peran krusial organisasi-organisasi desa dapat dilihat dari sumbangan mereka dalam mempromosikan pembangunan desa dengan jalan memberikan informasi yang lebih terinci mengenai kondisi-kondisi desa maupun peluang-peluang dari padà apa yang dilakukan oleh badan-badan pemerintah.

Lembaga-lembaga desa juga dapat menyesuaikan kebijaksanaan-kebijaksanaan dan prioritas-prioritas umum dengan kebu- 
tuhan-kebutuhan dan keadaan-keadaan tertentu. Dalam konteks ini, organisasi-organisasi desa dapat berpartisipasi dalam perencanaan dan penetapan tujuan pembangunan. Selain peran ini, lembaga-lembaga desa itu diperlakukan untuk mengatur penggunaan sumber-sumber yang diberikan oleh pemerintah pusat secara efektif dan untuk memobilisir sumber-sumber desa dalam proses pembangunan. Lebih dari itu, organisasi-organisasi desa dapat memainkan peran yang penting dalam menyalurkan input-input produksi dan memberikan pelayanan yang diperlukan oleh para petani maupun dalam mengelola input-input dan pelayanan yang berasal dari saluran dalam sistem lembaga.

Lembaga-lembaga desa itu dapat pula membantu sebagai sarana yang penting dalam memantau pemerintahan desa. Organisasi-organisasi desa dapat meningkatkan kemampuan para petani dalam berorganisasi secara efektif, sehingga para petani mempunyai kesempatan yang besar dalam mengartikulasikan kebutuhan-kebutuhan dan tuntutan-tuntutan mereka. Terakhir, peran organisasi desa adalah menghubungkan penduduk desa dengan lembaga-lembaga nasional yang menguasai sumber-sumber dan menetapkan kebijaksanaan. Dengan demikian, lembaga-lembaga petani dapat memberikan sumbangannya kepada keberhasilan pembangunan dalam memperbaiki produktivitas pertanian, memperluas kesempatan-kesempatan kerja dan memberikan pemerataan yang lebih besar dalam pembagian pendapatan desa (Uphoff and Esman, 1974).

\section{Pendekatan Pembangunan}

Menurut Uphoff dan Esman, peran organisasi desa yang bermakna dalam pembangunan, khususnya di sektor pertanian dipengaruhi oleh pendekatan-pende- katan pembangundan desa. Di satu pihak, pendekatan paternalistik mengatakan bahwa penduduk desa bersikap pasif dan fatalistik, tidak tertarik memprakarsai usahausaha memperbaiki kondisi-kondisi hidup mereka. Oleh karena itu, masyarakat desa dianggap tidak mampu mengembangkan organisasi-organisasi untuk memperbaiki kehidupan sosial dan ekonomi mereka. Atas dasar anggapan ini, pembangunan desa harus disponsori dan digerakkan oleh pemerintah. Dengan demikian, pola pembangunan dari atas (top-down) dinilai sebagai suatu strategi yang tepat untuk meningkatkan kesejahteraan masyarakat desa. Di lain pihak, pendekatan populistik mengatakan bahwa masyarakat desa pada dasarnya tertarik pada perubahan-perubahan dan mempunyai kemampuan untuk memperbaiki kondisi-kondisi hidup mereka, jika para birokrat dan para politisi tidak melakukan campur tangan. Menurut pandangan ini, masyarakat desalah yang paling mengetahui kondisi-kondisi hidup mereka. Oleh karena itu, pola pembangunan dari bawah (bottom-up) merupakan strategi yang paling baik untuk mencapai keberhasilan pembanguan desa.

Uphoff dan Esman berpendapat kombinasi strategi top-down dan bottom-up dapat menjadikan organisasi-organisasi desa efektif dalam menunjang pembangunan desa. Di satu pihak, pengawasan yang ketat dari pemerintah misalnya terhadap pemerataan distribusi input-input produksi sangat dibutuhkan. Di lain pihak, melalui organisasi-organisasi desa, penduduk desa dapat mengekspresikan kebutuhan-kebutuhan dan tuntutan-tuntutan maupun keluhan-keluhan kepada pemerintah.

Sementara itu Inayatullah berpendapat bahwa kemampuan organisasi-organisasi desa dalam melakukan fungsi-fungsi mereka secara efektif akan melemah jika pemerintah menggunakan strategi pemba- 
ngunan yang menyandarkan pada struktur birokrasi yang predominan. Kebutuhan untuk memusatkan kepada masalah-masalah yang berhubungan dengan stabilitas dan keamanan nasional memaksa pemerintah untuk mempercayakan pada birokrasi dan menghalangi timbulnya peran aktif lapisan masyarakat bawah (grassroots participation) melalui organisasi-organisasi desa dalam proses pembangunan. Dengan demikian dapat dikatakan bahwa strategi yang mempercayakan pada birokrasi (bureaucracy reliant strategy) digunakan sejalan dengan strategi yang memusatkan tujuan mencapai stabilitas (stability dominated strategy).

Strategi yang berfokus pada stabilitas merupakan bagian dari kebijaksanaan pemerintah karena pengalaman sejarah yang ditandai oleh instabilitas politik dan tekanan ideologi menyebabkan pemerintah cenderung memandang organisasi desa yang mendasarkan pada peran serta lapisan masyarakat bahwa sebagai bertentangan dengan usaha pemerintah untuk menciptakan stabilitas nasional. Menurut pandangan pemerintah, kegiatan-kegiatan partai politik dianggap dapat merusak solidaritas masyarakat desa. Di lain pihak, pemerintah memandang birokrasi sebagai suatu instrumen yang efektif dalam melaksanakan pembangunan desa dan mencapai tujuan-tujuan pembangunan. Sebagai instrumen dari pembangunan desa, birokrasi menjadi badan pemerintah dalam menangani masalah-masalah desa daripada sebagai badan yang mewakili penduduk desa kepada pemerintah. Lebih dari itu, dengan adanya rural depolitization menyebabkan birokrasi dapat menguasai political power. Dengan demikian kekuasaan dan kontrol terhadap sumber-sumber disalurkan melalui birokrasi.

Di negara-negara berkembang strategi yang mempercayakan pada birokrasi diper- gunakan untuk melaksanakan secara langsung program-program dan proyek-proyek pembangunan; melakukan pengorganisasian dan promosi organisasi-organisasi petani; mengawasi dan memeriksa keuangan dan memonitor organisasi-organisasi petani (Wanangsihe dalam Inayatullah, 1979, p. 488). Pengalaman juga menunjukkan bahwa strategi ini memungkinkan birokrasi bekerjasama dengan para elit desa. Struktur birokrasi yang predominan cenderung tidak merupakan mekanisme yang efektif untuk mengerahkan dan menggunakan energi semua penduduk desa bagi pembangunan. Organisasi-organisasi tidak lebih dari pembantu birokrasi untuk mengembangkan program revolusi hijau. Supra-village bureaucracy terlihat secara mendalam dalam pemilihan para pengurus organisasi-organisasi desa. Pemilihan semacam ini di satu pihak memelihara suatu aliansi yang kuat antara birokrasi dan para pengurus organisasi desa, dan di lain pihak, kurang adanya interaksi dari pengurus organisasi dengan anggota-anggotanya.

Penggunaan bureaucratic strategy juga paralel dengan top-down approach. Pola pembangunan top-down dan menyandarkan pada struktur birokrasi yang predominan membatasi devolusi pembuatan keputusan: dari pemerintah pusat ke masyarakat pada tingkat desa. Pelaksanaan pembangunan desa secara luas bergantung pada struktur birokrasi dari pusat politik menuju ke bawah ke masyarakat desa. Program-progam pembangunan desa dan organisasi-organisasi petani, diperkenalkan oleh pemerintah pusat dengan. kemungkinan kecil melakukan konsuitasi dengan lembagalembaga pemerintah daerah. Lebih dari itu, organisasi-organisasi desa cenderung merupakan lembaga-lembaga yang memberikan pelayanan bukan sebagai usaha-usaha yang mampu mendorong sendiri (self-propelling undertakings) yang mendapat du- 
Peran Organisasi Desa dalam Pembangunan di Taiwan, Budi Winarno

kungan dari masyarakat desa secara luas. Kurangnya inisiatif dan partisipasi rakyat bawah merupakan indikator kuat bahwa devolution of decision-making dari tingkat pemerintah yang lebih tinggi ke lembagalembaga desa sangat rendah. Hal ini akan mengurangi keefektifan organisasi-organisasi petani dalam memperbaiki kesejahteraan penduduk yang miskin.

Struktur birokrasi yang predominan ini merupakan instrumen yang secara relatif efektif guna memelihara dan mempertahankan land and order di daerah-daerah pedesaan, suatu kondisi yang diperlukan untuk menunjang growth strategy yang berorientasi kepada produktivitas desa dan secara efektif dapat membantu kebijaksanaan intervensi rendah. Kebijaksanaan yang berfokus pada pertumbuhan atau produktivitas sangat menghalangi organisasi-organisasi desa dan secara sungguhsungguh membatasi sumbangan-sumbangan yang diberikan oleh organisasiorgansasi desa dalam proses pembangunan yang luas.

Keengganan pemerintah untuk melakukan perubahan-perubahan struktural desa mengurangi kemampuan organisasi-organisasi petani untuk memainkan perannya yang besar dalam pembangunan desa. Program revolusi hijau hanya terbatas pada para petani yang mempunyai lahan luas karena mereka merupakan kelompok yang mampu menggunakan teknologi baru secara efektif. Kelompok petani ini cenderung mendapatkan peluang-peluang dalam memperoleh kredit murah dan input-input produksi yang telah disubsidi oleh pemerintah melalui organisasi-organisasi petani dan bank-bank desa. Konsekuensinya kebijaksanaan-kebijaksanaan pemerintah tidak hanya menyebabkan ketidakmampuan program-program pembangunan pertanian dalam menjangkau para petani miskin tetapi juga menghalangi para petani ini untuk mengartikulasikan kebutuhan-kebutuhan dasar dan keluhan-keluhan mereka kepada organisasi-organisasi desa.

\section{Peran Organisasi Desa}

Bagian berikut ini akan meneliti dan menilai peran organisasi-organisasi desa di dalam kerangka pembangunan pedesaan di tiga negara, yakni Taiwan, Thailand dan Philipina. Suatu analisis komparasi adalah penting untuk membantu meneliti kelemahan dan kekuatan organisasi-organisasi petani dalam peran mereka untuk pembangunan desa.

Program pembangunan pedesaan mempunyai dampak yang berbeda di Taiwan, Thailand dan Philipina. Di negaranegara ini, hasil pertanian dalam beras perhektar meningkat antara tahun 1950 dan 1982 (lihat tabel 1). Akan tetapi di Taiwan, hasil beras perhektar meningkat lebih besar dibandingkan dengan yang dicapai di Thailand dan Philipina. Tabel 2 menunjukkan bahwa distribusi pendapatan di derah pedesaan Thailand dan Philipina memburuk selama awal tahun 1970-an dibandingkan distribusi pendapatan riil di Taiwan dalam periode yang sama.

Suatu analisis komparasi tentang organisasi-organissi petani di Taiwan. Thailand dan Philipina menjelaskan dua perbedaan dalam kinerja organisasi-organisasi desa. Organisasi petani di Taiwan adalah efektif dalam memenuhi tujuan pembangunan pedesaan. Penggunaan kombinasi strategi transformasi teknologi dan pembaharuan kelembagaan memberikan sumbangan kepada keefektifan organisasi-organisasi desa. Program land reform menghancurkan dominasi elit desa melalui perhimpunan para petani (Fei, Ranis, and Kuo, 1979, p. 39). Dampak positifnya adalah semua petani dapat berperan serta secara sederajat dalam asosiasi-asosiasi petani dan mereka 
Peran Organisasi Desa dalam Pembangunan di Taiwan, Budi Winarno

Tabel 1

Hasil Beras Per Hektar di Taiwan, Thailand, dan Philipina 1950 - 1982 dalam Ton

\begin{tabular}{|l|c|c|c|}
\hline Tahun & Taiwan & Thailand & Philipina \\
\hline 1950 & 1,9 & 1,3 & 1,2 \\
1955 & 2,2 & 1,4 & 1,2 \\
1965 & 3,0 & 1,6 & 1,3 \\
1970 & 3,2 & 2,0 & 1,7 \\
$1976-1980$ & 4,4 & 1,8 & 2,1 \\
1981 & 4,7 & 1,9 & 2,4 \\
1982 & 4,9 & 1,8 & 2,4 \\
\hline
\end{tabular}

Sumber : T.H. Shen (ed.), Agriculture's Place in The strategy of Development: The Taiwan Experience (Taipei: Joint Commision on Rural Reconstruction, 1974, Appendix, p. 423). Richard W. Gable and Fred Springer, Agricultural Development in Asia: A Comparative Analysis of Four National Programs (Boulder: West View Press, 1976, p. 386). US Departement of Agriculture, Foreign Agricultural Circular. Grains (Washington, DC: Foreign Agricultural Services, September 9, 1983, p. 5).

Tabel 2

Distribusi Pendapatan di Daerah-Daerah Pedesaan Taiwan, Thailand, dan Philipina (Gini Coefficient)

\begin{tabular}{|l|l|c|}
\hline Negara & Tahun & Gini Coefficient \\
\hline Taiwan & 1962 & 0,21 \\
& 1967 & 0,18 \\
& 1972 & 0,29 \\
Thailand & $1962-1963$ & 0,44 \\
& 1970 & 0,45 \\
Philipina & 1961 & 0,41 \\
& 1965 & 0,43 \\
& 1971 & 0,47 \\
\hline
\end{tabular}

Catatan : Gini Coefficient adalah ukuran disparitas, semakin tinggi angka Gini, semakin tinggi pula disparitas pendapatan.

Sumber : Ajit Ghose and Keith Griffin, "Rural Poverty and Development Alternative in South and Southeast Asia: Some. Policy Issues, "Development and Change, 11: 4 (October, 1980) p. 552. Keith Griffin and Ajit Kumar Ghose, "Growth and Improverishment in the Rural Areas of Asia, Development 7; 4/5 (April/May 1979), p. 367. 
mempunyai akses yang sama dalam pelayanan dan kegiatannya. Dengan demikian, mereka memperoleh keuntungan dari program Revolusi Hijau.

Pengawasan langsung dari pemerintah terhadap perhimpunan ini secara khusus adalah penting karena pengawasan itu dapat meningkatkan efektivitas organisasi. Dengan didukung oleh polisi dan diperkuat oleh badan-badan pemaksa undang-undang, pemerintah tidak hanya mengawasi kegiatan-kegiatan organisasi petani, akan tetapi juga menghukum mereka yang terlibat dalam praktek-praktek ilegal lainnya. Pengawasan dari pemerintah memung-. kinkan organisasi desa memiliki kapasitas lebih besar dalam melayani kepentingan para warga desa. Meskipun aktivitas organisasi yang diawasi secara ketat oleh pemerintah, lembaga-lembaga petani itu masih memiliki power untuk menyalurkan pandangan petani, yang berkaitan dengan pembangunan pedesaan kepada pemerintah. Pola-pola pembangunan dan perubahan sosial top-down dan bottom-up secara nyata memberikan sumbangan kepada asosiasi-asosiasi petani untuk mendukung program-program pembangunan pedesaan secara efektif.

Tidak seperti halnya di Taiwan, pengalaman pembangunan di Thailand dan Philipina menunjukkan bahwa negara-negara ini, organisasi-organisasi pedesaan yang sangat sedikit memberikan sumbangan yang bermakna dalam melayani kebutuhan para petani yang miskin. Di dua negara ini, organisasi-organisasi desa dibentuk oleh pemerintah dan aktivitas mereka diawasi oleh pemerintah. Di sisi lain, pemerintah memperlemah lembaga-lembaga petani yang mempunyai basis massa. Tidak adanya komitmen politik untuk memperbarui lembaga-lembaga pertanian menyebabkan pemerintah secara khusus menyandarkan pada pembaharuan teknologi untuk mencapai tujuan-tujuan pembangunan desa.

Kegagalan program land-reform dan peranan penting pembangunan pedesaan diserahkan kepada birokrasi (Simpas, Carino and Pacho, 1974; Inayatullah, 1979) merongrong kemampuan organisasi-organisasi petani. Para elit di desa-desa secara terusmenerus mendominasi lembaga-lembaga petani dan banyak menerima keuntungan dari program Revolusi Hijau. Di dua negara ini para petani miskin ditindas dan dihalanghalangi untuk berperan sederajat dalam organisasi. Akibatnya. masalah-masalah kemiskinan, petani tidak memiliki lahan tanah, pengangguran dan kesenjangan antara pemilik dan penyewa tanah (petani gurem) semakin memburuk. Singkat kata, pendekatan pembangunan desa yang menekankan top-down menghalangi organișasi-organisasi petani menjadi wahana yang efektif bagi pembangunan desa.

\section{Kesimpulan}

Sebagaimana kebanyakan negara-negara berkembang, di Taiwan, Thailand dan Philipina berupaya untuk melaksanakan pembangunan pedesaan. Masing-masing negara ini telah menerapkan berbagai strategi yang berbeda-beda untuk mengimplementasikan modernisasi pertanian. Di Taiwan, pembangunan desa mendasarkan pada penggabungan strategi-strategi transformasi teknologi dan reorganisasi lembaga-lembaga yang ada. Didukung oleh kebijaksanaan pembangunan dan perubahan sosial top-down dan bottom-up, peran asosiasi-asosiasi petani menjadi semakin efektif dalam proses pembangunan desa.

Di Thailand dan Philipina, pemerintah berpendapat bahwa birokrasi merupakan sarana yang paling efektif bagi pembangunan desa. Pertumbuhan organisasiorganisasi petani yang berbasiskan massa 
dianggap sebagai suatu ancaman terhadap kekuasaan dan kedudukan istimewa birokrasi pemerintah. Keengganan pemerintah untuk memberikan peluang memperkuat organisasi-organisasi petani dicerminkan dalam strategi mereka. Dengan menerapkan suatu pendekatan teknokratik, pemerintah sangat menginginkan peningkatan produktivitas dan produksi beras. Namun yang paling besar mendapat keuntungan dari strategi pembangunan ini adalah para tuan tanah yang memiliki akses program pembangunan. Pendekatan top-down dalam perencanaan pembangunan dan formulasi kebijaksanaan secara substansial membatasi kemampuan organisasi-organisasi petani ini untuk melaksanakan program pembangunan pedesaan yang dapat melayani kebutuhan para petani miskin.

\section{Daftar Pustaka}

Gable, Richard W., and J. Fred Springer, Agricultural Development in Asia: Comparative of Four National Programs (Boulder, Co.,: Westview Press, Inc., 1976).

Ghose, Ajit and Keith Griffin, "Rural Poverty and Development Alternatives in South and Southeast Asia: Some
Policy Issues," Development and Change, 11: 4 (October 1980), pp. 545-592.

Griffin, Keith and Ajit Kumas Ghose, "Growth and Impoverishment in the Rural Areas of Asia", Development 7; 4/5 (April/May 1979).

Inayatullah (ed.), Rural Organizations and Rural Development: Some Asian Experiences, (Kuala Lumpur: Asian and Pasific Development Administration Centre, 1978).

Shen, T.H. (ed.), Agriculture's Place in the Strategy of Development The Tai : wan Experience (Táipel Joint Commision on Rural 'Recontruction,; 1974).

Simpas, Santiago S., Ledivina Cạino, áñd arturo G. Pacho, Local Government and Rural Development in the Phiiippines (Ithaca, N.Y: Rural Development Committee, Centre Forrinternational Studies, Cornell University, 1974).

Uphoff, Norman T., and Milton J. Esman;:Local Organization for Rural Devel: opment: Analysis of Asian Experience. (Ithaca, N.Y: Rural Development Committee, Center for International Studies, Cornell University, 1974). 